\title{
International Relation: The Trade War between the United States and China
}

\author{
Jingjie Lin \\ Rabun Gap, Nacoochee School, GA. \\ jlin@rabungap.org
}

\section{INTRODUCTION}

From both a military and economic perspective, the United States of America and the People's Republic of China represent two of the most powerful countries in the world. Since their initial interaction, the relationship between these two nations has been at times amicable and at other times confrontational. After the election of Donald Trump in 2016, the tension between the two has grown, especially with respect to Chinese economic policies, which the U.S. has long claim were unfairly organized. The present trade war between the U.S. and China is one of the most important but also controversial issuestoday. While it is still boiling, the international society is hopefully seeking ways to eliminate the tension and to restore peaceful economic relations. This paper will assess the present trade war from two perspectives. First, it will situate the disagreement between China and the U.S. in historical context, looking back to moments in history that have led up to the present engagement. Secondly, the paper will address potential strategies that the two nations can pursue as the attempt the negotiate their differences. This paper argues that the primary cause of the trade war is the shift in China from a purely manufacturing economy to a technological one. This shift has created enormous anxiety in America, specifically around the question of national security. The present trade war represents the American attempt to regain control of this sector.

\section{HistoricAl BACKGROUND}

About two centuries ago, China and the United States began official trade relations. "Contact between the U.S. and China began in August 1792 when the Empress of China sailed to Guangzhou, a province in southern China." This marks the beginning of a new era of international trading and economic integration. In 1834, a further step forward was taken. In that year, Dr. Peter Parker, the first medical missionary, arrived in China. He set up a small clinic, which attracted thousands of patients and expanded to what was known as Guangzhou Hospital. Five years after him, in 1839, a merchant from Philadelphia, Nathan Dann, who spent 12 years trading with China, imported a vast collection of art, artifacts, botanic samples and more to the United States. He established a museum that allowed visitors "a glimpse into life in China"2. This represents the beginning of U.S.-China cultural communications.

Later on, the U.S. and China either confronted and cooperated along with the wars. With China's failures in the Opium War, which began as an attempt to open Chinese markets for silk, porcelain, and tea to British and American traders, eventually concluded with the Treaty of Wangxia. This treaty gave Americans privileges in China, but was also marked "the beginning of official relations between the two countries." $\mathrm{After}$ the failure in the first Sino-Japanese war, China, was introduced to the "open door" idea by Secretary of State, John Hay, who promoted "equal tradeopportunities in China for foreign powers." In essential, the policy was meant to ensure that no country would assume complete economic control over China. In response to the grown power that western powers were exerting, the Boxer Rebellion took place in the late 1890s. Driven by anti-foreign 
sentiment, the Rebellion aimed to wrest China from the clutches of foreign powers. A common slogan of the Boxers was "support the Qing, destroy the foreigner." The rebellion was crushed after ten years, and the Qing dynasty was forced to pay $\$ 330$ million for reparations. The anti-foreign sentiment in China was still growing, and it soon change to anti-American sentiment. In 1906, major cities in China started to boycott American products and businesses. The relation between U.S. and China continuously weakened, until the "Rape of Nanjing," an inhumane massacre against Chinese civilians, took place in 1938. The U.S., U.K., Australia, and France limited the trade with Japan and financially supported China, and more on, US volunteered in Chinese air force, nicknamed "flying tiger", helped defending China.

The year 1949 marks a significant change in the history of U.S.-China relations. This is theyear in which the Chinese civil war concluded with the victory of the Communist Party. Following this event, the relationship between China and U.S can be divided into three time periods, each defined by the American strategy towards the newlyformed Communist government: containment, rapprochement, full diplomatic relation. ${ }^{4}$ During the period of Containment, which lasted from 1949 to 1969, "the United States tried to disrupt, destabilize, and weaken China's communist government."Washington took this approach because it considered China an aggressive, expansionist country that would threaten the security of non-communist neighbors.Along China's eastern and southern borders,the United States constructed an offshore line of military alliances, which included Japan, South Korea, and the Nationalist government on Taiwan. Additionally, the United States formed the Southeast Asian Treaty Organization(SEATO), which included Thailand, the Philippines, and South Vietnam, and ANZUS Treaty that linked Australia, New Zealand, and the United States. ${ }^{5}$ The United States maintained military bases in countries such as Japan and South Korea and encouraged their allies to refrain from entering into diplomatic relations with Beijing. Trade between China and the U.S. was cut off, and people were prohibited to visit China. Around 1960, in attempt to further isolate China and to diminish the possible spread of Communism, the United States pursued the "wedge strategy," which attempted to separate China and the Soviet Union. This was eventually successful and marks the pinnacle of America's strategic engagement in this period.

After containment, the United Statesinitiated rapprochement, which China and United States move closer and unofficially relation was developed. President Nixon's visit in 1972 was a breakthrough for rapprochement. Nixon and China's primer, Zhou Enlai, signed the Shanghai Communique. As part of this agreement,the United States acknowledged Taiwan as part of China.The United States agreed not to challenge what became known as the One-China policy. After this agreement, the United States withdrew military power from Taiwan, and military force in Taiwan were reduced as a tension. On this basis, "U.S.-China unofficial relations began to develop, with trade, educational, and cultural exchanges." ${ }^{\prime \prime}$ In 1979, China and United States established full diplomatic relation. United States broke the formal diplomatic relation with Taiwan, but Congress passedthe Taiwan Relations Act, which "commits the United States to help maintain Taiwan's self-defense capacity and to consider coming to its defense if it is attacked by mainland China." ${ }^{7}$ The formal diplomatic relation opened up trade, investment, tourism and reduced economic barriers between China and United States. However, both governments still remained dissatisfiedon some issues: "On the American side, these included dissatisfaction with Chinese human rights policies, with China's large trade surpluses with the United States, and with China's sales of missiles and nuclear technology to countries in the Middle East and elsewhere. On the Chinese side, the biggest issue was continued American arms sales to Taiwan. In addition to this, China criticized American global foreign policy as one which tried to enforce American interests and did not pay enough attention to the interests of other countries."8 In assessing the contemporary trade war, and in attempting to define the most effective strategy for dealing with it, we must keep this long and complex history in mind. It is impossible, for example, to understand China's economic maneuvers without recognizing the long historical memory that it has of the treat of Wanxia, which effectively gave the United States unequal treatment. 
International Relation: The Trade War between the United States and China

\section{TRADE WAR BETWEEN CHINA AND U.S.}

There is no doubt that after Trump became president of the United States, tensions between China and United States began to raise. Long before Trump was elected, historical context proved this situation would happen. On September 21, 2011, Trump tweeted that "China is neither an ally or a friend-they want to beat us and own our country." This is one of many statements Trump made before becoming president that reveal his attitude toward both the Chinese government and the most effective means of confronting it. ${ }^{9}$ Trump's comment toward China didn't come from nowhere. In the $21^{\text {st }}$ century, America's trade deficit has continuously grown, from \$-83.174 billion in 2001 to \$-367.554 billion in 2015.In comparison, China haddeveloped a trade surplus of roughly $\$ 260.912$ billion by 2015 . However,at the end of 2016 , China's trade surplus dropped from $\$ 260.912$ to $\$ 256,223$. These numbers illustrate the growing tension between the two nations, both of which were striving to create favorable economic conditions.

There were achievements of peace while the tension was warming up between China and U.S... In April 6-7, 2017, President Xi visited Trump in Florida, in order to solve the trade difference. In the meeting, President Trump did not "explicitly rule out slapping tariffs on Chinese goods," which threatened doing as "a response to the bilateral trade imbalance and a comparative lack of market access for US companies in China." ${ }^{10}$ President Xi offered Trump "tweetable deliverables," ${ }^{11}$ such as lifting bans on U.S. beef, increasing pork and soybean import, and show more Hollywood movies on the mainland. However, the meeting did not go well: Trump did not endorse either of China's two principal international projects: the Asia Infrastructure Investment Bank and the One Belt, One Road. The attempt on assuaging tension between U.S. and China initially failed, not until May 22, 2017, the U.S. and China made a trade deal which gave U.S. companies greater access to China's "agriculture, energy and financial markets", while China gains access to "sell cooked poultry to the U.S."12

However, the mitigation of trade deficit is only half way solving the trade war, in U.S. perspective, the other element is the technology security problem which China existed "technology thieves" who steal products and patents from U.S. companies. Under this circumstance, the situation warmed up after Trump's state visit in November 8-10, 2017, three months after the USTR initiated an "investigation into certain acts, policies and practices of the Chinese government relation to technology transfer, intellectual property and innovation".13

The investigation turned more practicable in March 22, 2018, when President Trump signed a memorandum, with three main points: "To file a WTO case against China for their discriminatory licensing practices; to restrict investment in key technology sectors; to impose tariffs on Chinese products (such as aerospace, information communication technology and machinery)." ${ }^{14}$ The next day, March 23, the U.S. imposed"a 25 percent tariff on all steel imports (except from Argentina, Australia, Brazil, and South Korea) and a 10 percent tariff on all aluminum imports (except from Argentina and Australia)". ${ }^{15}$

As the world's largest steel exporter, China is the biggest victim of this policy. In 2019, China exported 66.9 million metric tons of steel, "a 9 percent decrease from 73.3 million metric tons in 2017," and the U.S. received "734,8 thousand metric tons in 2018, a6 percent decrease from 2017" according to the International Trade Administration. ${ }^{16}$ In order to fight back, China imposed "tariff on 128 products, which worth $\$ 3$ billion, including fruit, wine, seamless steel pines, pork and recycled aluminum in retaliation to the US's steel and aluminum tariffs" in April 2, 2018. The next day, the U.S. released an "initial list of 1,334 proposed products about $\$ 3$ billion to a potential 25 tariff." China also reacted to the list and proposed " 25 percent tariffs to be applied on 106 products about $\$ 50$ billion on goods such as soybeans, automobile, chemicals". ${ }^{17}$

Engagements between the U.S. and China did not stop, and even upgraded into sanction of firms. In April 16, 2018, the Department of Commerce concluded that "Chinese telecom company ZTE violated US sanction; US companies are banned from doing business with ZTE for seven years." In response, China announced antidumping duties of 178.6 percent on imports of sorghum from the U.S. After one month, Trump promised 
to help ZTE in a tweet, and China announces that "it will stop tariff on U.S. sorghum at negotiations" after five days. In June 15 to 16, 2018, both sides had finalized the list of products: US had list one which implements a 25 percent tariff on a 818 products and list two of 284 new products will announced under consideration; China revised the tariff list to 25 percent tariff on 545 products, equaling $\$ 34$ billion and proposed a "second round of 25 percent tariff on further 114 products (valued at US \$billion)." Both tariffs will take effect on July 6, 2018. ${ }^{18}$

\section{THE DEVELOPMENT OF 5G}

The development of present trade policies has a significant impact on firms and industries, and this is most apparent with respect to the technology sector. To understand this influence, it is necessary look back to 2006 when a long-term policy was enacted that affected billions of people, and that is the ban on Google in China mainland. Since 2006, China has been the second largest economic body in accounted as GDP and world's largest economic purchasing power. According to Forbes, "China has turned its image from a copycat economy to a hotbed of innovation." With the ban of Google, a company called Baidu, which was 297 on the Forbes' “Global 2000 2019", with market capital of \$59.7Billion, established a Chinese research engine. ${ }^{20}$ Comparing with Google, which Forbes valuedat $\$ 132$.1billion in 2018, Baidu could be considered as hugely successful, given that it operates in a single language.The case of Baidu helps reveal that the Chinese government was seeking to establish a series of Chinese firms, instead of introducing international companies. Indeed, this theory is proved by Uber's "pull out" and Amazon's struggle on China's mainland, with the replacement of ride sharing business Didi and online market Alibaba. Therefore, it is hard for Chinese government to use foreign companies to control its competitive power in the international market. Indeed, it was a great grievance for so many big firms to quite such a large economic body, but it also confirms that firms could also be used as chesses pieces in the competitions of countries.

In May 16, 2019, The US Department of Commerce announced the placement of Huawei Technology, a Chinese technology giant, on the "entity list." As a result of this listing, bans U.S. companies are banned from selling to the Chinese telecommunications company "without US government approval". The reason behind this restriction is that "Huawei is engaged in activities that are contrary to US national security or foreign policy interest" including alleged "violations of the International Emergency Economic Powers Act(IEEPA), conspiracy to violate IEEPA by providing prohibited financial services to Iran, and obstruction of justice in connection with the investigation of those alleged violations of US sanction," according to the US Department of Commerce. However, this issue may also connect to the first test of 5G. On March 30 in Shanghai, Wu Qing, Shanghai's vice mayor, made the network's first video call using Huawei Mate X, a foldable 5G smartphone, according to the Xinhua News Agency. It doesn't look like a coincidence that the ban of Huawei in the U.S. came two months after the first test of 5G on Huawei's smartphone. In effect, the ban shows that the U.S.'s response to China's technological growth is an aggressive set of policies that are meant to hinder further development of Chinese ability.

The ban of Huawei leads to a more substantial question: Why US take $5 \mathrm{G}$ so seriously? According to the Xin Hua News Agency, 5G network is able to provide a peak single-user download speed of $1.6 \mathrm{Gbps}$, nearly 16 times faster than 4G service. What $5 \mathrm{G}$ means is not only "faster download", but also greater improvements that can have destabilizing effects on the social, political, and military orders. For example, China could "weaponize cities" if controlled 5G, according to a retired US general, who described the possibilities of having a bunch of military robots in the battle field controlled by human, instead of flash-to-flash. ${ }^{23}$ Nevertheless, the expert say $5 \mathrm{G}$ is more susceptible to hacking than previous networks, which means the country has higher supremacy on5G can control over a vast areas of technology.

What the U.S.' attention is that China exceeded US in the race to formulate 5G. Until March 30, 2019, "a total of 228 5G stations have been deployed in Hongkou, making it the first district in Shanghai fully covered by a 5G network and a gigabit broadband network."21 The director of Shanghai Municipal Commission of Economy and 
Informatization also claims that "the city aims to build over 10,000 5G base stations by the end of the year, and the number is expected to exceed 30,000 by $2021 .{ }^{\prime 22}$ In contrast, Sprint, a U.S. telecommunication giant, has announced a "May launch for its 5G network in a handful city," with the coming of the Samsung Galaxy S10 5G. According to Newsroom, Sprint plants to begin its mobile 5G rollout in the first half of 2019, applies on nine 5G markets include some of the largest cities in US such as Atlanta, New York city. The 5G war had begun, and the ban of Huawei proved that.

\section{THEORY AND STRATEGY}

In the Trump era trade war, perspective from the U.S. administration is significant. The theory of Realism defined by Anne Marie Slaughter best demonstrates Trump's views of U.S.-China relation. According to Slaughter, in Realism, the international system is defined by anarchy, the absence of authority. She also claims that there is no inherent structure or society can emerge or even exist to order relation between them. What this means to the U.S.-China relationship is not that both sides negotiate without a governing authority that can ensure that the behave in accordance with anything other than their own best interest. Organizations such as WTO(the World Trade Organization) or the United Nations are unable to control either side. The theory of Realism also believes that the countries are bound only by force. As such, the best way to ensure survival and growth is to develop economic and military strength that can be leveraged against other nations. In the vision of Realism, the world rest on four assumptions.Survival is the principle of every country, especially against defending foreign invasion and occupation. The domestic interest will indicate more benevolent than international goals. Secondly, countries are considered as rational actors, which means they will act as best as they can in order to maximize the chance they can exist. Thirdly, countries all possess some military power,and none know what their neighbors intend. In other word, the relation between countries will be dangerous and uncertain.Lastly, power is decisive. The international relation is essentially a story of Great Power politics. Trump's earlier statement about China wanting to "beat us down and own our country" reveals that he sees the world in realist terms: as a zero-sum game in which one country wins and the other loses. This mentally is evident in the way Trump is pursuing an aggressive, confrontational approach to China.

In distinction, Liberalism is a theory of international relations that is predicated upon shared values and cooperation. In the theory of Liberalism, national characteristics of individual states matter for their international relations. In other word, unlike Realism, which assumes that all states act in accordance with the same motivation, Liberalism emphasize the importance of domestic development in the international relationship. Moreover, one development of the Liberal theory, called Democratic Peace, describes the ideal situation that liberal countries seek to have-the absence of war.The theory states that liberal democracies are much less likely to go to war with one another. As a result, liberalism attempts to promote freedom of the press and of the vote, hoping that countries will become better integrated into the community of nations as they move away from authoritarian forms of government. Therefore, Democratic Peace can be almost approach while enhancing economical balance in both sides. With the existence of Realism in US side, the deadlock of trade war can be break only if both US and China change competing to accommodation.

There are three goals of trade war: protect the national enterprise, put pressure on the opposite economic body, and retain supremacy in technological development. To achieve Democratic Peace between China and US, both sides should decrease the conflict bilaterally. The U.S. and China should refrain from policies that harm the cooperation between giant technology firms, such as Google and Huawei.Instead, they must encourage and support their trade by lowering tariffs on technological raw material. The U.S. government can support them when necessary in the name of national security, in order to balance the competing between U.S. companies and Chinese SOEs. The goal is to keep the speed of technological development for both countries, thus staying ahead of the world. Second, the U.S. and China should slightly reduce their overall tariffs. Some tariffs are needed to protect local enterprises, but an overall reduction will assist consumers on both ends. Additionally, the WTO 
International Relation: The Trade War between the United States and China

should set a maxum tariff for both countries and impose penalties if the deal is broken. According to Andrew Moravcsik, liberal theory is based on three core assumptions, and the topmost is that individuals and private groups are the fundamental actors in world politics. Therefore, the U.S. and China should focus the policy target on development of local enhancement and daily life of citizens, instead of international competing that can lead to more conflicts. It is a long, difficult way to achieve Domestic Peace, but it will be a significant milestone of world history and humanity when it's approached. The U.S. and China, therefore, should work together, turning the intense trade war into the ideal Domestic Peace.

\section{REFERENCES}

\section{1, 2, 3 U.S.-China Relations: A Brief Historical Perspective. Compiled and written by Erin Monroe}

4,5,6,7,8 U.S.-China Relations Since 1949, 2009 Asia for Educators, Columbia University| http://afe.easia. columbia.edu

9,10,11.12,13,14,15,16,17,18,19 www.china-briefing,com/news/the-us-china-trade-war-a-timeline, The USChina Trade War:A Timeline, written and composed by Dorcas Wong and Alexander Chipman Koty www. trade,gov/steel/countries/exports/china.asp, Enhanced Global Steel Trade Monitoring, International Trade Administration

20www.forbes.com/sites/cognitiveworld/2018/08/30/why-china-is-a-no-go-land-for-google/\#1ac88805 5b3c, Why China Is A No-Go Land For Google, Kate Levchuk, Aug 30, 2018, 12:10am

21,22 www.xinhuanet.com/english/2019-03/30/c_137936750.htm, Shanghai's 5G network starts test runs, editor: zh,2019-03-30 21:55:40

23www.scmp.com/news/china/militray/article/2194483/why-5g-battleground-us-and-china-also-fightmilitary-supremacy, Why 6G, a battleground for US and China, is also a fight for military supremacu, Liu Zhen, 6:00PM, 31 Jan, 2019

Citation: Jingjie Lin, "International Relation: The Trade War between the United States and China". American Research Journal of History and Culture, vol 5, no. 1; pp: 1-6.

Copyright (c) 2019 Jingjie Lin. This is an open access article distributed under the Creative Commons Attribution License, which permits unrestricted use, distribution, and reproduction in any medium, provided the original work is properly cited. 